\title{
Interactions between stream fungi and bacteria associated with decomposing leaf litter at different levels of nutrient availability
}

\author{
Vladislav Gulis*, Keller Suberkropp** \\ Department of Biological Sciences, University of Alabama, PO Box 870206, Tuscaloosa, Alabama 35487, USA
}

\begin{abstract}
We examined the potential for interactions between aquatic hyphomycetes and bacteria isolated from leaves decaying in a headwater stream. In agar plate assays, culture filtrates of each of 28 aquatic hyphomycete isolates tested (5 species) inhibited bacterial growth (16 Gram-negative bacterial isolates belonging to 6 colony morphotypes were tested). Inhibition of bacterial growth occurred in $20 \%$ of the combinations. To determine whether such interactions could occur on decomposing leaves, Articulospora tetracladia (isolate 24-4) and bacterial isolate B2NPM3-1 (tentatively placed in Comamonadaceae) were grown in axenic and dual cultures on leaf litter in microcosms. Performance of both microorganisms was estimated by measuring leaf mass loss, fungal and bacterial biomass, conidia production, respiration and calculating carbon flow through different microbial compartments in 2 treatments that differed with respect to inorganic nutrient ( $\mathrm{N}$ and $\mathrm{P}$ ) concentrations. High fungal antagonistic activity demonstrated in plate assays was not corroborated in microcosms. Cumulative Articulospora tetracladia production decreased 21 to $24 \%$ in 2 -membered microcosms regardless of nutrient level, whereas the bacterial isolate exhibited a differential response (1.7 times lower cumulative production in the low nutrient and $52 \%$ increase in the high nutrient treatment in 2-membered cultures compared with axenic cultures), suggesting that nutrient availability may modify microbial interactions. Fungal performance (yield coefficient and production efficiency) was not affected in 2-membered microcosms, whereas the bacterial yield coefficient was 1.7 to 2.2 times lower when grown with the fungus in comparison to axenic cultures. We observed only antagonistic or competitive interactions and no signs of synergistic relationships causing faster leaf litter decomposition or resulting in enhanced microbial production. Overall, the interactions were relatively mild and did not affect fungal dominance in the transformation of leaf organic matter.
\end{abstract}

KEY WORDS: Antagonism - Aquatic hyphomycetes · Articulospora tetracladia - Microbial biomass · Respiration · Carbon budget · Inorganic nutrients

\section{INTRODUCTION}

Allochthonous organic material is a primary source of energy and nutrients for small shaded woodland streams (Fisher \& Likens 1973). Microorganisms are important intermediaries of energy flow from submerged decaying plant litter to higher trophic levels (Suberkropp \& Klug 1976, Bärlocher \& Kendrick 1981).

*Present address: Departmento de Zoologia, Universida de Coimbra, 3004-517 Coimbra, Portugal

${ }^{* *}$ Corresponding author. Email: ksuberkp@biology.as.ua.edu
According to current concepts in stream ecology, aquatic fungi dominate the decomposition of leaf litter (Findlay \& Arsuffi 1989, Baldy et al. 1995, Weyers \& Suberkropp 1996) that may result from antagonistic interactions with bacteria. Such indications were also obtained by earlier researchers (Kaushik \& Hynes 1968, Chamier et al. 1984). However, the only study (Bengtsson 1992) that has specifically addressed interactions between fungi and bacteria associated with submerged leaf litter in a laboratory microcosm suggested that fungal-bacterial interactions were synergistic. 
Laboratory studies by Platas et al. (1998) and Gulis \& Stephanovich (1999) have demonstrated that 58 and $52 \%$, respectively, of aquatic hyphomycete species tested inhibited bacterial growth in plate assays involving antibiotic production. A few compounds with antibacterial properties have been obtained from aquatic hyphomycetes and their chemical structures resolved (Harrigan et al. 1995, Oh et al. 1999). Vining (1990) convincingly argued that production of secondary metabolites by microorganisms may be ecologically significant. Antibiotic substances in particular improve survival fitness of producing organisms by affecting competitors.

However, one should be cautious in attempting to generalize results of laboratory findings to natural situations. It is not clear whether production of antibiotic substances occurs under natural conditions in fast flowing streams and, if so, whether this gives fungi a competitive advantage over bacteria. Shearer \& ZareMaivan (1988) suggested that in lotic ecosystems inhibitory substances excreted by fungi are likely to be washed away. On the other hand, the same might be true for fungal hydrolytic enzymes, which are definitely active in the natural environment (e.g. Chamier 1985, Jenkins \& Suberkropp 1995). Perhaps, in both cases, substances are immobilized close to fungal hyphae or within decaying plant tissue by means of mucilage secretion or other mechanisms.

Fungi and bacteria associated with submerged decaying leaf litter are closely associated spatially even though hyphae can penetrate the substrate, while bacterial cells are thought to be restricted to leaf surfaces with the exception of tunneling bacteria (Porter et al. 1989) and possible bacterial 'epiphytes' on fungal hyphae. Hence, it is plausible to assume that these microorganisms can affect each other through a variety of mechanisms, such as direct resource competition, production of secondary metabolites with antibiotic activity or supply of growth factors.

Eutrophication can directly influence microbial activity through elevated nutrient concentrations (especially $\mathrm{N}$ and $\mathrm{P}$ ) and consequently affect plant litter decomposition (Suberkropp \& Chauvet 1995, Sridhar \& Bärlocher 2003, Grattan \& Suberkropp 2001, Gulis \& Suberkropp 2002). However, we currently have no indication if such enrichment can affect microbial interactions in stream ecosystems. In view of this, the objectives of this study were: (1) to screen a number of aquatic hyphomycete isolates for their ability to produce substances inhibitory to bacterial isolates from decomposing leaf litter; (2) to determine whether fungi exhibit antagonistic activity toward bacteria when they are grown together on leaf litter in streamsimulating microcosms; and (3) to determine whether potential interactions between these microorganisms would be altered as a result of nutrient enrichment.

\section{MATERIALS AND METHODS}

Preliminary screening. Fungi and bacteria for laboratory experiments were isolated in December 2000, from submerged red maple Acer rubrum L. leaves decaying in the headwater stream draining catchment 54 at Coweeta Hydrologic Laboratory, North Carolina, USA. Single spore isolates of each aquatic hyphomycete species that displayed high sporulation rates from maple leaf litter in a previous study (Gulis \& Suberkropp 2003), and hence were active in leaf litter decomposition, were obtained in accordance with Descals (1997). A total of 28 isolates belonging to 5 species (Alatospora acuminata Ingold [6], Anguillospora filiformis Greathead [5], Articulospora tetracladia Ingold [10] Tetrachaetum elegans Ingold [4] and Tricladium chaetocladium Ingold [3]) were used in a preliminary screening. For bacteria isolation, leaf material was homogenized in sterile deionized water and serial dilutions were used to inoculate plates of low strength PYG (peptone $0.1 \%$, yeast extract $0.02 \%$, glucose $0.1 \%$, agar 2\%; Suberkropp \& Klug 1976) that were incubated at $15^{\circ} \mathrm{C}$ for $5 \mathrm{~d}$. The most abundant colony morphotypes were picked and isolates were purified by streaking on fresh plates. A total of 16 isolates representing 6 morphotypes were used for further screening experiments. All of them were straight or slightly curved Gram-negative rods.

Aquatic hyphomycetes were cultured in $125 \mathrm{ml}$ Erlenmeyer flasks each containing $20 \mathrm{ml}$ of potato broth prepared as for potato dextrose agar (Hawksworth et al. 1995), and then filtered and supplemented with $10 \mathrm{~g} \mathrm{l}^{-1}$ maltose; $\mathrm{pH}$ was adjusted to 6.0 with $\mathrm{KOH}$. Each flask was inoculated with 3000 conidia (sporulation was induced by cutting pieces from fungal colonies grown on malt extract agar and aerating them in deionized water for $3 \mathrm{~d}$ ). After incubation at $15^{\circ} \mathrm{C}$ for $28 \mathrm{~d}$, culture broths were bioassayed against bacteria using the well method. A volume $(3.5 \mathrm{ml})$ of warm $\left(45^{\circ} \mathrm{C}\right)$ low strength PYG $(0.7 \%$ agar $)$ containing approximately $10^{6}$ bacterial cells was poured over a layer of $12 \mathrm{ml}$ PYG ( $2 \%$ agar) in $90 \mathrm{~mm}$ Petri dishes. Aliquots of aquatic hyphomycete culture broth $(100 \mu \mathrm{l})$ were placed in wells ( $8 \mathrm{~mm}$ in diameter, 7 per plate) and incubated at $15^{\circ} \mathrm{C}$ for $4 \mathrm{~d}$. The diameter of the zone of clearing around the well, if any, was measured.

Laboratory microcosms. Articulospora tetracladia 24-4 and bacterial isolate B2NPM3-1 were used for laboratory microcosm studies. Each aeration chamber (glass cylinder, $33 \mathrm{~mm}$ in diameter $\times 120 \mathrm{~mm}$ long with aeration and drain tubes attached and covered with a glass cap; Suberkropp 1991) was autoclaved, filled with $40 \mathrm{ml}$ nutrient solution (see below) and received 15 preweighed red maple leaf disks $(11.8 \mathrm{~mm}$ in diameter). They were cut from autumn-shed leaves, 
leached for 3 to $4 \mathrm{~d}$ in deionized water at $5^{\circ} \mathrm{C}$, dried at $60^{\circ} \mathrm{C}$ for 2 to $3 \mathrm{~d}$, weighed in sets of 15 and sterilized with $\gamma$-irradiation (2 to 3 megarads). Microcosms were inoculated either with 3000 conidia of A. tetracladia, $1 \times 10^{9}$ bacterial cells from $5 \mathrm{~d}$ old PYG plates (nephelometry calibrated by DAPI count [see below], equal to $2 \times 10^{8}$ colony forming units on PYG plates) or both microorganisms. Microcosms were incubated at $15^{\circ} \mathrm{C}$ in an incubator with glass doors, thus exposing cultures to light levels present in the laboratory. Microcosms were aerated with 80 to $100 \mathrm{ml}$ air min $^{-1}$ (flow meter regulated). Air inlets of each microcosm were plugged with cotton to eliminate contamination of the microcosms. Two solutions with contrasting nutrient concentrations were used. The low nutrient solution contained $1.4 \mu \mathrm{M} \mathrm{N}$ (from $\mathrm{NH}_{4} \mathrm{NO}_{3}$ ) and $0.06 \mu \mathrm{M} \mathrm{P}$ (from $\mathrm{KH}_{2} \mathrm{PO}_{4}$ ), whereas a high nutrient solution had $143 \mu \mathrm{M} N$ and $6.25 \mu \mathrm{M}$ P, thus spanning a large portion of the range of nutrient variability occurring in lotic ecosystems (Allan 1995). Solutions were buffered with MOPS (3-[N-morpholino]propanesulfonic acid, $0.25 \mathrm{~g}$ $\mathrm{l}^{-1}$ ), adjusted to $\mathrm{pH} 7.0$ with $\mathrm{KOH}$ and autoclaved. The fluid in the aeration chambers was replaced every $2 \mathrm{~d}$ to keep the nutrient concentration relatively constant as well as to determine losses of bacteria to the fluid and sporulation rate of the aquatic hyphomycete. On each sampling date, 9 chambers were sacrificed for each nutrient level (3 replicates for $A$. tetracladia, bacteria or both). Fluid and 5 disks (separately) were sampled from each chamber for bacteria; 10 disks and the remaining fluid were used for respiration measurements. Five of these disks were then preserved in methanol for determination of fungal biomass and 5 were used to establish leaf mass loss.

Leaf mass loss. Sets of 5 leaf disks were dried at $100^{\circ} \mathrm{C}$ for at least $2 \mathrm{~d}$, weighed and the ash-free dry mass (AFDM) was calculated for each sampling date by applying the average ash content of $4.1 \%$ determined from combustion of sets of leaf disks at $500^{\circ} \mathrm{C}$ at the beginning and the end of the experiment. Six sets of 15 leaf disks sampled after $1 \mathrm{~d}$ soaking were used to estimate handling losses and the conversion factor that allowed initial AFDM of each set used in this study to be calculated from dry masses.

Fungi. Every 2 d, chambers were drained into beakers, $0.1 \mathrm{ml}$ of a $0.5 \%$ Triton X-100 was added and suspensions were stirred to ensure uniform distribution of conidia (Suberkropp 1991). Dilutions were made if necessary. Two to $4 \mathrm{ml}$ of suspension were filtered through membrane filters (Millipore, $5 \mu \mathrm{m}$ pore size) and stained with trypan blue in lactic acid $(0.1 \%)$. Two filters were prepared for each replicate and Articulospora tetracladia conidia in a total of 50 fields (1.08 $\mathrm{mm}^{2}$ per field) were counted (Leitz Laborlux, $160 \times)$.
Five leaf disks after respiration measurement were preserved in $5 \mathrm{ml}$ methanol in $20 \mathrm{ml}$ scintillation vials and used to determine fungal biomass associated with leaf material. Ergosterol was extracted and determined by comparing absorbance at $282 \mathrm{~nm}$ after separation by HPLC (Shimadzu) with standard concentrations of ergosterol (Fluka) (Newell et al. 1988 as modified by Suberkropp \& Weyers 1996). To convert ergosterol concentrations to fungal biomass, we assumed an ergosterol concentration of $5.5 \mu \mathrm{g} \mathrm{mg}^{-1}$ of mycelial dry mass (Gessner \& Chauvet 1993).

Bacteria. Four ml of fluid and 5 leaf disks from each aeration chamber were preserved with $1 \mathrm{ml}$ of $10 \%$ buffered formalin or $5 \mathrm{ml}$ of $2 \%$ buffered formalin made in saline (final concentration $8.5 \mathrm{~g} \mathrm{NaCl} \mathrm{l}^{-1}$ ), respectively. Bacteria were enumerated with epifluorescence microscopy following staining with DAPI (Velji \& Albright 1993). Samples were prepared, and bacteria counted and sized according to Gulis \& Suberkropp (2003). Mean cell biovolume estimate for bacterial isolate B2NPM3-1 was $0.26 \mu^{3}$, yielding a carbon content of $4.06 \times 10^{-8} \mu \mathrm{g} \mathrm{C}$ cell $^{-1}$ (equal to

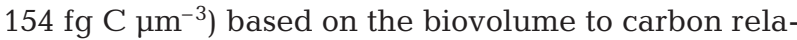
tionship in Simon \& Azam (1989). We found that ultrasonication of leaf material to dislodge bacteria (Velji \& Albright 1993, Weyers \& Suberkropp 1996, Buesing \& Gessner 2002) underestimated bacterial biomass in our case by a factor of 7.8 as inferred from counts made from red maple leaf disks that were ground with a tissue homogenizer (unpubl. data). Similar results have been obtained by other researchers (see Buesing \& Gessner 2002 for discussion). Consequently, bacterial biomass estimates from leaf disks (but not fluids) were corrected.

Respiration. Ten disks in fluid from each microcosm were placed in respiration chambers $(26 \mathrm{ml})$ to determine oxygen uptake at $15^{\circ} \mathrm{C}$ by recording dissolved oxygen concentration with a YSI 5100 dissolved oxygen meter (Yellow Springs, $\mathrm{OH}$ ) for $30 \mathrm{~min}$. Additional chambers containing nutrient solution served as controls. Oxygen uptake was determined from the slope of regression of oxygen concentration versus time, minus the control slope determined from nutrient solution alone.

Statistical analyses and carbon budgets. Decomposition rates, $k$, were estimated by linear regression of $l n$ transformed data (exponential model). Differences in $k$ were determined with analysis of covariance (ANCOVA) followed by Tukey's test to compare slopes among treatments. Effects of microbial community and nutrient availability on fungal biomass, sporulation rate of aquatic hyphomycetes, bacterial biomass and microbial respiration were tested by repeated measures ANOVA (Zar 1984). Data derived from conidia and bacteria counts were $\ln (x+1)$ transformed before 
Table 1. Inhibition of bacterial growth by aquatic hyphomycetes presented as percent of combinations where clearing zones on bacterial lawns caused by fungal culture broths were observed. A total of 16 bacterial isolates were tested

\begin{tabular}{|c|c|c|c|c|c|}
\hline & \multicolumn{5}{|c|}{ Aquatic hyphomycete (no. isolates) } \\
\hline & $\begin{array}{c}\text { Alatospora } \\
\text { acuminata (6) }\end{array}$ & $\begin{array}{l}\text { Anguillospora } \\
\text { filiformis (5) }\end{array}$ & $\begin{array}{c}\text { Articulospora } \\
\text { tetracladia (10) }\end{array}$ & $\begin{array}{l}\text { Tetrachaetum } \\
\text { elegans (4) }\end{array}$ & $\begin{array}{c}\text { Tricladium } \\
\text { chaetocladium (3) }\end{array}$ \\
\hline $\begin{array}{l}\text { Percent of combinations with } \\
\text { inhibitory effect }\end{array}$ & 11 & 16 & 21 & 38 & 17 \\
\hline
\end{tabular}

analyses. Carbon budgets were calculated assuming $50 \%$ carbon content of leaf AFDM and fungal dry mass, and a respiratory quotient of 1 . Total bacterial production from fluid, total conidia production and leaf carbon losses due to respiration (after linear interpolation of missing data) were estimated by summing up over the entire experiment. Dry mass of Articulospora tetracladia conidium was assumed to be $0.86 \mathrm{ng}$ (Chauvet \& Suberkropp 1998). Data analyses were conducted using SYSTAT 10.

\section{RESULTS}

Screening of 28 aquatic hyphomycete isolates against 16 bacterial isolates showed that in 90 combinations $(20 \%)$, fungi produced substances that inhibited bacterial growth as judged by clearing zones in the bacterial lawns around wells containing the fungal culture broth (Table 1). One bacterial isolate was inhibited by all fungi and 6 isolates were not affected

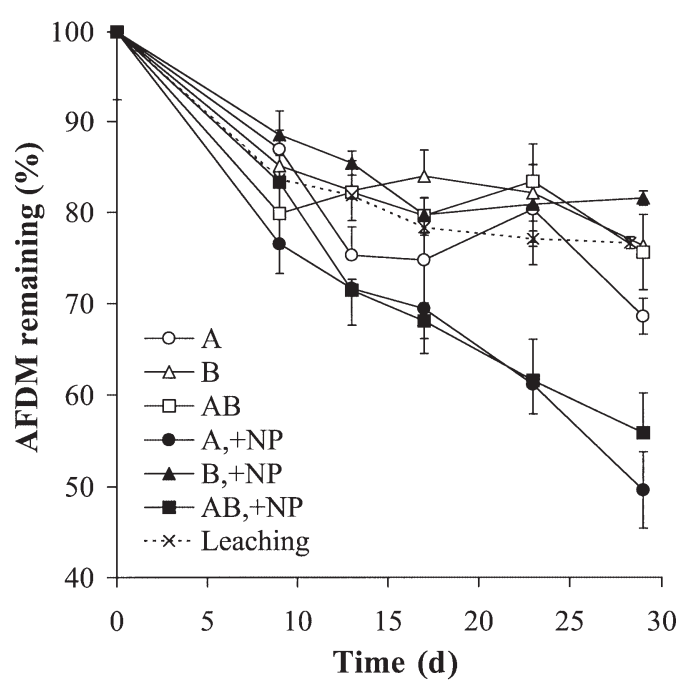

Fig. 1. Mass loss of maple leaf disks inoculated in laboratory microcosms. A: Articulospora tetracladia; B: bacteria; AB: both organisms in control and nutrient enrichment (+NP) treatments or left sterile (Leaching). Symbols indicate mean $\pm 1 \mathrm{SE} ; \mathrm{AFDM}$ : ash-free dry mass by culture broths of any of the aquatic hyphomycetes tested.

On the basis of results from the preliminary survey, we chose Articulospora tetracladia (isolate 24-4) and bacterial isolate B2NPM3-1 for growth experiments on leaf litter in stream-simulating microcosms. This combination exhibited inhibition zones of up to $21 \mathrm{~mm}$ in diameter and, we assumed, would exhibit the maximum difference in bacterial performance alone and in 2-membered microcosms. Bacterial isolate B2NPM3-1 remained unidentified on the basis of 16S rDNA gene sequence similarity (515 bp, MIDI Labs). Sequence analysis performed using PE Applied Biosystem's Microseq ${ }^{\mathrm{TM}}$ microbial analysis software and database as well as gene alignment with GenBank did not result in species or genus level matches. However, 9 out of 10 closest matches were from Proteobacteria, $\beta$-subdivision, family Comamonadaceae or Burkholderia group.

Decomposition rates of maple leaf disks in microcosms containing low levels of nutrients irrespective of associated microorganisms and in the high nutrient treatment inoculated only with bacteria were not significantly different from the decomposition rate of the abiotic control (ANCOVA, p > 0.05; Fig. 1, Table 2). At the high nutrient concentration, fungi contributed significantly to leaf mass loss with breakdown coefficients as high as 0.0228 and $0.0207 \mathrm{~d}^{-1}$ for leaf disks inoculated with Articulospora tetracladia alone and with

Table 2. Decomposition rates $(k)$ of maple leaf disks inoculated in laboratory microcosms. A: Articulospora tetracladia; $\mathrm{B}$ : bacteria; $\mathrm{AB}$ : both organisms in control and nutrient enrichment $(+\mathrm{NP})$ treatments or left sterile (Leaching). Confidence limits $(95 \%)$ are included. Different letters indicate significant differences $(\mathrm{p}<0.05)$ among slopes using Tukey's test

\begin{tabular}{|lllll|}
\hline Treatment & $k\left(\mathrm{~d}^{-1}\right) \pm 95 \% \mathrm{CL}$ & $\mathrm{r}^{2}$ & \\
\hline $\mathrm{A}$ & $0.0121 \pm 0.0044$ & 0.64 & $\mathrm{a}$ \\
$\mathrm{B}$ & $0.0088 \pm 0.0036$ & 0.58 & $\mathrm{a}$ \\
$\mathrm{AB}$ & $0.0086 \pm 0.0042$ & 0.49 & $\mathrm{a}$ \\
$\mathrm{A},+\mathrm{NP}$ & $0.0228 \pm 0.0041$ & 0.88 & $\mathrm{~b}$ \\
$\mathrm{~B}_{1}+\mathrm{NP}$ & $0.0080 \pm 0.0035$ & 0.54 & $\mathrm{a}$ \\
$\mathrm{AB},+\mathrm{NP}$ & $0.0207 \pm 0.0040$ & 0.86 & $\mathrm{~b}$ \\
Leaching & $0.0099 \pm 0.0029$ & 0.74 & $\mathrm{a}$ \\
& & & & \\
\hline
\end{tabular}




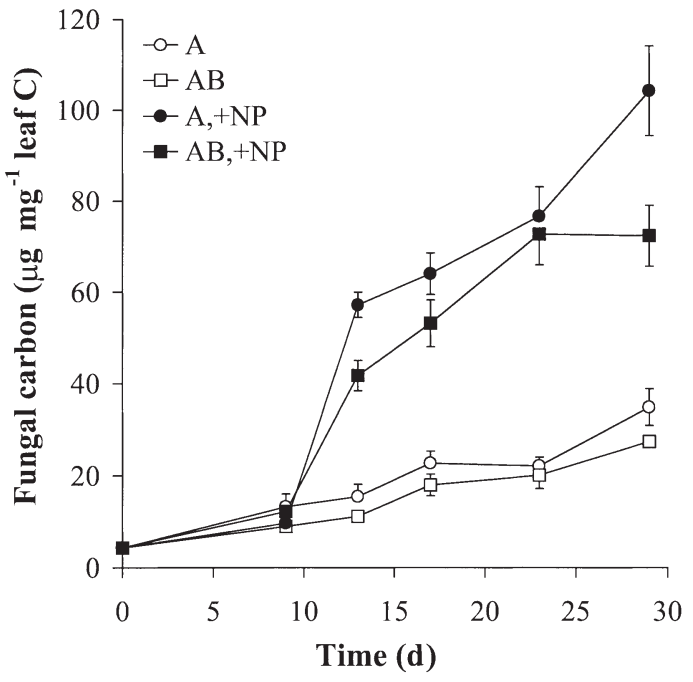

Fig. 2. Fungal biomass associated with leaf disks. For abbreviations see Fig. 1. Symbols indicate mean $\pm 1 \mathrm{SE}$

both microorganisms, respectively, versus $0.0099 \mathrm{~d}^{-1}$ in the abiotic control (ANCOVA, $\mathrm{p}<0.001$; Table 2).

Fungal biomass accrual was slightly higher on leaf material inoculated with Articulospora tetracladia alone than in 2-membered microcosms in low nutrient treatments (Fig. 2), but differences were not significant (ANOVA, $p=0.12$ ). Fungal biomass reached significantly higher values in axenic fungal cultures at high nutrient concentrations in comparison to dual cultures $(p<0.003)$. Elevated nutrient concentrations had a significant positive effect on fungal biomass irrespective of bacterial presence $(p<0.001)$, allowing roughly 3 times higher fungal biomass by the end of the experiment in comparison to the low nutrient treatments.

Presence of bacteria delayed sporulation and reduced conidia production by Articulospora tetracladia at both nutrient levels (ANOVA, $p=0.006$ and $\mathrm{p}<$ 0.001 , low and high nutrient treatments, respectively; Fig. 3). Conidia production was strongly stimulated by higher nutrient availability ( $\mathrm{p}<0.001$ ), exceeding those in the low nutrient treatment by more than 1 order of magnitude, and reaching peaks of 10.7 and 7.6 conidia $\mu g^{-1}$ leaf AFDM d ${ }^{-1}$ in microcosms inoculated with fungi and both microorganisms, respectively, versus only 2.1 and 0.6 conidia $\mu^{-1}$ leaf AFDM $\mathrm{d}^{-1}$ attained in the low nutrient treatment by the end of experiment.

Bacteria in the experimental microcosms fell into 2 subpopulations. One was closely associated with leaf material, while the other was represented by bacteria suspended in the fluid in the chambers. Relative contributions of these 2 subpopulations to total bacterial carbon of the microcosm changed over time. Steady increases in bacterial biomass associated with leaf litter (Fig. 4A) compensated for the gradual decline of the bacterial subpopulation in the fluid (Fig. 4B). Statistical analysis of pooled data from both subpopulations (Fig. 4C) showed no effect of fungal presence on bacterial biomass at either low (ANOVA, $\mathrm{p}=0.31$ ) or high nutrient concentrations $(p=0.32)$. Significant effects of nutrient availability on bacterial biomass were apparent $(p=0.011$ and $p<0.001$ for microcosms with bacteria only and with both microorganisms, respectively). Nearly the same results of statistical analyses were obtained for the bacterial subpopulation associated with leaf material. However, patterns of bacterial biomass in fluid allowed us to detect the effect of fungal presence. Fungi inhibited increases in bacterial numbers in fluid in the low nutrient microcosms; however, stimulation was observed at high nutrient concentration $(\mathrm{p}<0.001$ for both comparisons; Fig. 4B).

Respiration rates in treatments with Articulospora tetracladia were always higher in comparison to microcosms containing leaf disks inoculated with bacteria only (ANOVA, $p=0.01$ and $p=0.002$, fungus alone, low and high nutrients, respectively; $p=0.02$ and $\mathrm{p}<0.001,2$-membered microcosms, low and high nutrient treatments, respectively; Fig. 5). Addition of bacteria did not change oxygen uptake significantly $(\mathrm{p}=0.36$ and $\mathrm{p}=0.16$, low and high nutrient treatments, respectively). Positive effects of higher nutrient availability on respiration were significant in all cases ( $\mathrm{p}<0.007, \mathrm{p}=0.001$ and $\mathrm{p}<0.001$, leaf material inoculated with $A$. tetracladia, bacteria and both microorganisms, respectively).

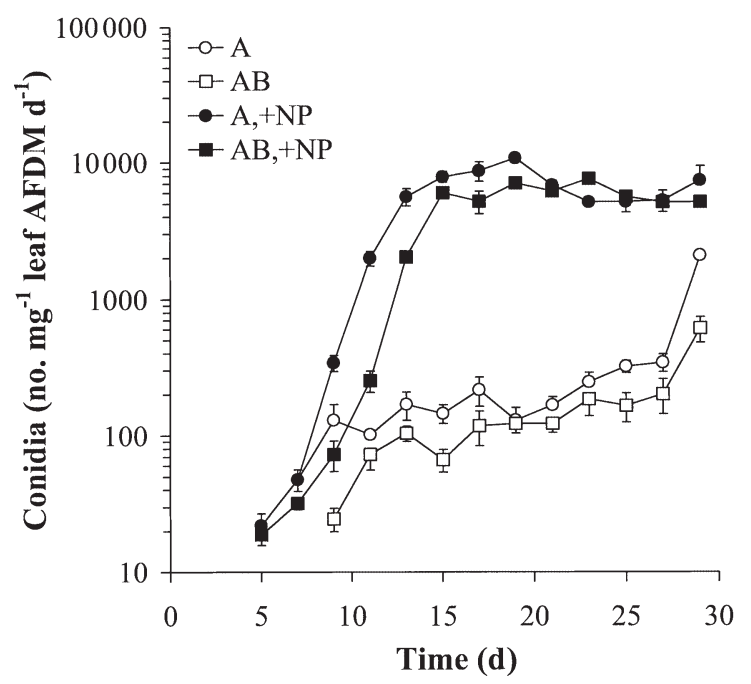

Fig. 3. Articulospora tetracladia. Sporulation rate on leaf disks in laboratory microcosms. For abbreviations see Fig. 1. Symbols indicate mean $\pm 1 \mathrm{SE}$ 


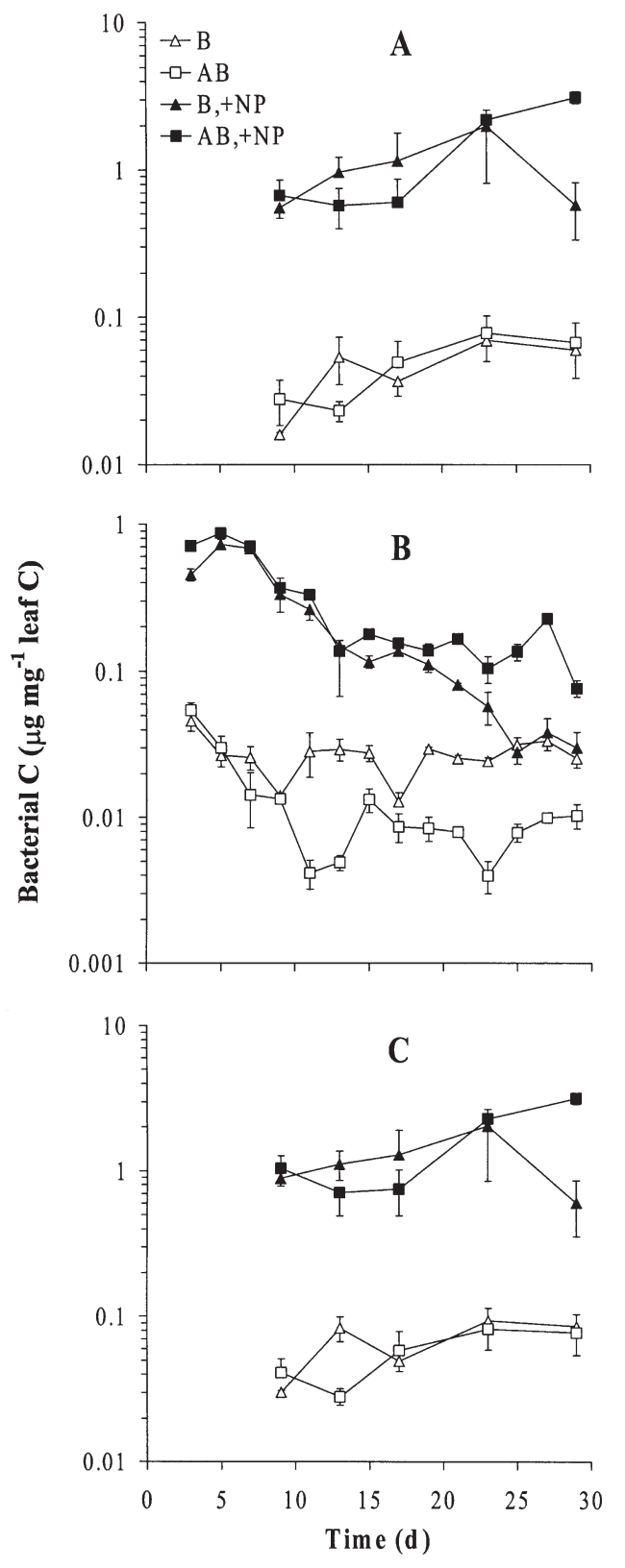

Fig. 4. Bacteria in experimental microcosms. (A) Associated with maple leaf disks, (B) suspended in fluids, (C), pooled data from (A) and (B). For abbreviations see Fig. 1. Symbols indicate mean $\pm 1 \mathrm{SE}$

Partial carbon budgets calculated for each treatment are given in Table 3. Carbon losses due to leaf material fragmentation (fine particulate organic carbon, FPOC) and leaching (dissolved organic carbon, DOC) were not directly measured, but they were considerable since only 12 to $39 \%$ of leaf mass loss is explained by these budgets. Hence, fungal production was probably underestimated due to losses of mycelial fragments with FPOC that were not taken into account.

\section{DISCUSSION}

Plate assays demonstrated that all isolates of 5 aquatic hyphomycete species that dominated on red maple leaf litter in the stream (Gulis \& Suberkropp 2003) were able to inhibit at least some of the bacterial isolates obtained from the same source. Antagonistic activity of aquatic hyphomycetes due to release of diffusible inhibitory substances has been demonstrated previously (Platas et al. 1998, Gulis \& Stephanovich 1999), but no bacteria isolated from aquatic environments were tested in those studies. The antagonistic abilities of at least 1 isolate of Articulospora tetracladia, however, were not corroborated in microcosms that simulated stream conditions and with leaf material as the carbon and energy source.

Some of the parameters estimating activity and performance of microorganisms during leaf litter decomposition suggest that fungal-bacterial interactions did occur in our microcosm experiments. Bacteria had a negative effect on mycelial production and sporulation (Table 3). Cumulative fungal production (biomass accumulation plus conidia production) in dual cultures was lower by 24 and $21 \%$ in low and high nutrient treatments, respectively. This is explained by the fact that gains in fungal biomass and increases in sporulation rate were delayed in the presence of bacteria. Cumulative bacterial production (biomass accumulation on leaf disks and production from fluid) in the presence of Articulospora tetracladia was 1.7 times lower than for bacteria alone in the low nutrient treatment due to decreased bacterial shedding from leaf disks and/or growth in fluid (Table 3). In contrast, in

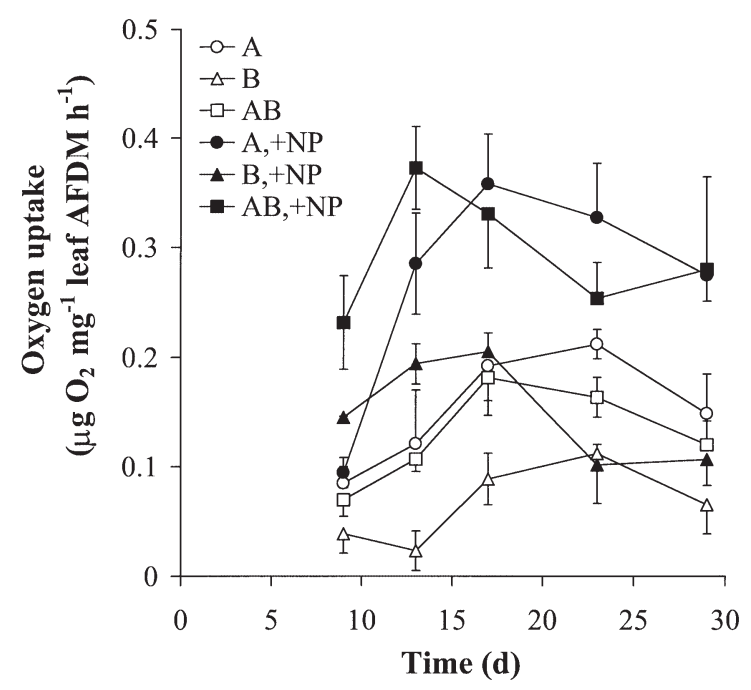

Fig. 5. Respiration of microorganisms from laboratory microcosms. For abbreviations see Fig. 1. Symbols indicate mean $\pm 1 \mathrm{SE}$ 
Table 3. Carbon budget for microorganisms associated with decomposing maple leaf disks in laboratory microcosms. For abbreviations see Table 1. Data are means $\pm 1 \mathrm{SE}$. Leaf mass loss was corrected for final microbial biomass associated with leaf disks. Yield coefficient $=$ cumulative production/leaf mass loss, production efficiency $=$ cumulative production/(cumulative production + respiration $)$, explained mass loss $=($ cumulative production + respiration $) /$ leaf mass loss

\begin{tabular}{|c|c|c|c|c|c|c|}
\hline \multirow{2}{*}{ Parameter } & \multicolumn{6}{|c|}{ Treatment } \\
\hline & A & $\mathrm{B}$ & $\mathrm{AB}$ & $\mathrm{A}_{1}+\mathrm{NP}$ & $\mathrm{B},+\mathrm{NP}$ & $\mathrm{AB},+\mathrm{NP}$ \\
\hline Leaf mass loss $(\%)$ & $33.8 \pm 2.2$ & $23.7 \pm 5.4$ & $26.5 \pm 4.1$ & $55.5 \pm 4.3$ & $18.5 \pm 0.8$ & $48.4 \pm 4.3$ \\
\hline 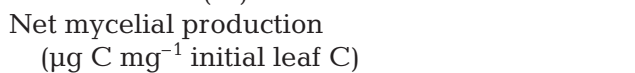 & $19.5 \pm 2.2$ & & $16.3 \pm 0.9$ & $46.5 \pm 1.5$ & & $35.6 \pm 2.4$ \\
\hline $\begin{array}{l}\text { Total conidia production } \\
\qquad\left(\mu \mathrm{g} \mathrm{C} \mathrm{mg}^{-1} \text { initial leaf } \mathrm{C}\right)\end{array}$ & $5.2 \pm 0.5$ & & $2.5 \pm 0.3$ & $67.2 \pm 2.1$ & & $54.4 \pm 2.8$ \\
\hline $\begin{array}{l}\text { Cumulative fungal production } \\
\quad\left(\mu \mathrm{g} \mathrm{C} \mathrm{mg}^{-1} \text { initial leaf } \mathrm{C}\right)\end{array}$ & $24.6 \pm 1.8$ & & $18.8 \pm 1.1$ & $113.7 \pm 1.8$ & & $90.1 \pm 2.0$ \\
\hline $\begin{array}{l}\text { Net bacterial production on leaf disks } \\
\quad\left(\mu \mathrm{g} \mathrm{C} \mathrm{mg}^{-1} \text { initial leaf } \mathrm{C}\right)\end{array}$ & & $0.05 \pm 0.02$ & $0.05 \pm 0.02$ & & $0.47 \pm 0.20$ & $1.75 \pm 0.28$ \\
\hline 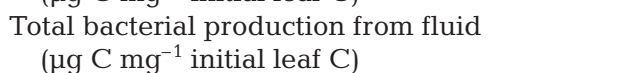 & & $0.34 \pm 0.01$ & $0.17 \pm 0.00$ & & $2.93 \pm 0.02$ & $3.40 \pm 0.12$ \\
\hline $\begin{array}{l}\text { Cumulative bacterial production } \\
\left(\mu \mathrm{g} \mathrm{C} \mathrm{mg}^{-1} \text { initial leaf } \mathrm{C}\right)\end{array}$ & & $0.38 \pm 0.02$ & $0.22 \pm 0.02$ & & $3.40 \pm 0.21$ & $5.15 \pm 0.27$ \\
\hline Yield coefficient-Articulospora tetracladia (\%) & $7.3 \pm 0.4$ & & $7.5 \pm 1.5$ & $20.8 \pm 2.0$ & & $19.0 \pm 2.0$ \\
\hline Yield coefficient-bacteria (\%) & & $0.19 \pm 0.06$ & $0.09 \pm 0.01$ & & $1.84 \pm 0.12$ & $1.09 \pm 0.15$ \\
\hline Respiration ( $\mu \mathrm{g} \mathrm{C} \mathrm{mg}^{-1}$ initial leaf $\mathrm{C}$ ) & $52.4 \pm 2.1$ & $25.0 \pm 2.9$ & $45.5 \pm 4.6$ & $75.0 \pm 4.1$ & $56.0 \pm 4.1$ & $87.9 \pm 7.2$ \\
\hline Microbial production efficiency (\%) & $31.9 \pm 1.2$ & $1.6 \pm 0.3$ & $29.8 \pm 3.0$ & $60.3 \pm 1.2$ & $5.8 \pm 0.7$ & $52.2 \pm 1.7$ \\
\hline Explained mass loss $(\%)$ & $22.8 \pm 0.6$ & $11.6 \pm 2.0$ & $25.1 \pm 2.5$ & $34.6 \pm 3.9$ & $32.1 \pm 1.6$ & $38.7 \pm 4.7$ \\
\hline
\end{tabular}

the high nutrient treatment, bacterial production in 2membered microcosms was $52 \%$ higher than in microcosms with bacteria alone. Respiration in axenic and dual cultures suggested competitive or antagonistic interactions between microorganisms (Table 3), while decomposition rate was a poor indicator due to insignificant leaf mass loss caused by bacteria and appreciable losses of organic carbon as DOC and FPOC.

We speculate that a number of factors could be responsible for the complex situation observed. Microbial biomass dynamics (Figs. $2 \& 4 \mathrm{~B}$ ) suggest that fungi were outcompeted by bacteria for simple readily available organic substances during the initial stage of leaf disk decomposition when leaching allowed bacterial proliferation in fluid. Bengtsson (1992) also reported better growth of bacteria in fluid than on leaves in experimental microcosms. However, these data are not directly comparable because fluids were not changed during the course of those experiments (Bengtsson 1992), resulting in build up of leaf leachate that favor bacteria. Wohl \& McArthur (2001) found that aquatic actinomycetes depressed fungal growth when inoculated simultaneously, presumably due to rapid initial growth of the former associated with the availability of dissolved organic matter. Newell \& Fell (1997) observed that marine bacteria that were allowed to precolonize leaf material inhibited invasion of the substrate by Halophytophthora species (primary eukaryotic mycelial decomposers of submerged leaf litter in mangrove systems).
Development of abundant superficial and intramatrical hyphae and maceration of leaf material by aquatic hyphomycetes at later stages of decomposition (Suberkropp \& Klug 1980) greatly enhances surface area available for bacterial colonization. In this study, we also observed growth of bacteria closely associated with both living and senescent/dead fungal hyphae. Aquatic hyphomycetes secrete a range of extracellular enzymes that attack structural polymers of plant cell walls (Chamier 1985, Shearer 1992 and references therein), and bacteria should benefit from the products of the enzymatic degradation of leaf material, simple carbohydrates and/or growth factors available in the close vicinity of fungal hyphae. In turn, fungi may have developed defense mechanisms to protect resources. We believe that production of antibacterial substances by Articulospora tetracladia by the middle of the experiment in the low nutrient treatment overcame benefits that bacteria had from close association with hyphae. The production of antibiotic substances by aquatic hyphomycetes is favored by growth media with a low N:C ratio (Platas et al. 1998). Consequently, at the higher nutrient concentration, antibiotic production by $A$. tetracladia may have been repressed, which could have resulted in the net stimulation of bacterial growth that we observed.

Overall fungal performance in leaf carbon transformation (Articulospora tetracladia yield coefficient and microbial production efficiency, essentially fungal; Table 3) was not affected by the presence of bacteria. In contrast, yield coefficients of bacteria, i.e. percent- 
age of leaf carbon lost channeled to bacterial production, were 2.2 and 1.7 times lower in microcosms inoculated with both microorganisms in low and high nutrient treatments, respectively, in comparison to bacteria alone. Irrespective of bacterial presence or nutrient level, A. tetracladia showed higher cumulative production (17 to 85 times), yield coefficient (11 to 87 times) and production efficiency (10 to 20 times, axenic cultures only were compared) than bacteria. All this points to better fungal performance in the decomposition of recalcitrant leaf biopolymers (lignocellulose), ability to outcompete bacteria in resource competition and emphasizes the major role of fungi in leaf litter decomposition in a wide range of freshwater ecosystems (Baldy et al. 1995, Suberkropp \& Chauvet 1995, Komínková et al. 2000).

In the present study, no signs of synergistic relationships such as observed by Bengtsson (1992) that would cause faster leaf litter decomposition or result in enhanced microbial production were noted in our 2membered microcosms. Growth of the fungal isolate was always slightly inhibited in dual microcosms regardless of nutrient level; whereas, the bacterial isolate demonstrated a differential response suggesting that nutrient availability may modify microbial interactions in aquatic ecosystems. Nevertheless, these interactions had relatively small effects and did not affect dominance of fungi in microbial transformations of leaf organic matter.

Acknowledgements. This work was supported in part by the North Atlantic Treaty Organization under NSF-NATO Postdoctoral Fellowship in Science and Engineering awarded to V.G. and by NSF grant DEB 9806610.

\section{LITERATURE CITED}

Allan JD (1995) Stream ecology: structure and function of running waters. Chapman and Hall, London

Baldy V, Gessner MO, Chauvet E (1995) Bacteria, fungi and the breakdown of leaf litter in a large river. Oikos 74: 93-102

Bärlocher F, Kendrick B (1981) Role of aquatic hyphomycetes in the trophic structure of streams. In: Wicklow DT, Carroll GC (eds) The fungal community: its organization and role in the ecosystem. Marcel Dekker, New York, p 743-760

Bengtsson G (1992) Interactions between fungi, bacteria and beech leaves in a stream microcosm. Oecologia 89: 542-549

Buesing N, Gessner MO (2002) Comparison of detachment procedures for direct counts of bacteria associated with sediment particles, plant litter and epiphytic biofilms. Aquat Microb Ecol 27:29-36

Chamier AC (1985) Cell-wall degrading enzymes of aquatic hyphomycetes: a review. Bot J Linn Soc 91:67-81

Chamier AC, Dixon PA, Archer SA (1984) The spatial distribution of fungi on decomposing alder leaves in a freshwater stream. Oecologia 64:92-103

Chauvet E, Suberkropp K (1998) Temperature and sporula- tion of aquatic hyphomycetes. Appl Environ Microbiol 64 $1522-1525$

Descals E (1997) Ingoldian fungi: some field and laboratory techniques. Boll Soc Hist Nat Mus Balears 40:169-221

Findlay SE, Arsuffi TL (1989) Microbial growth and detritus transformations during decomposition of leaf litter in a stream. Freshw Biol 21:261-269

Fisher SG, Likens GE (1973) Energy flow in Bear Brook, New Hampshire: an integrative approach to stream ecosystem metabolism. Ecol Monogr 43:421-439

Gessner MO, Chauvet E (1993) Ergosterol-to-biomass conversion factors for aquatic hyphomycetes. Appl Environ Microbiol 59:502-507

Grattan RM, Suberkropp K (2001) Effects of nutrient enrichment on yellow poplar leaf decomposition and fungal activity in streams. J North Am Benthol Soc 20:33-43

Gulis VI, Stephanovich AI (1999) Antibiotic effects of some aquatic hyphomycetes. Mycol Res 103:111-115

Gulis V, Suberkropp K (2003) Leaf litter decomposition and microbial activity in nutrient-enriched and unaltered reaches of a headwater stream. Freshw Biol 48:123-134

Harrigan GG, Armentrout BL, Gloer JB, Shearer CA (1995) Anguillosporal, a new antibacterial and antifungal metabolite from the freshwater fungus Anguillospora longissima. J Nat Prod 58:1467-1469

Hawksworth DL, Kirk PM, Sutton BC, Pegler DN (1995) Ainsworth and Bisby's dictionary of the fungi, 8th edn. Cambridge University Press, Cambridge

Jenkins CC, Suberkropp K (1995) The influence of water chemistry on the enzymatic degradation of leaves in streams. Freshw Biol 33:245-253

Kaushik NK, Hynes HBN (1968) Experimental study on the role of autumn-shed leaves in aquatic environments. J Ecol 56:229-243

Komínková D, Kuehn KA, Büsing N, Steiner D, Gessner MO (2000) Microbial biomass, growth, and respiration associated with submerged litter of Phragmites australis decomposing in a littoral reed stand of a large lake. Aquat Microb Ecol 22:271-282

Newell SY, Fell JW (1997) Competition among mangrove oomycotes, and between oomycotes and other microbes. Aquat Microb Ecol 12:21-28

Newell SY, Arsuffi TL, Fallon RD (1988) Fundamental procedures for determining ergosterol content of decaying plant material by liquid chromatography. Appl Environ Microbiol 54:1876-1879

Oh H, Kwon TO, Gloer JB, Marvanová L, Shearer CA (1999) Tenellic acids A-D: new bioactive diphenyl ether derivatives from the aquatic fungus Dendrospora tenella. J Nat Prod 62:580-583

Platas G, Pelaez F, Collado J, Villuendas G, Diez MT (1998) Screening of antimicrobial activities by aquatic hyphomycetes cultivated on various nutrient sources. Cryptogam Mycol 19:33-43

Porter D, Newell SY, Lingle WL (1989) Tunneling bacteria in decaying leaves of a seagrass. Aquat Bot 35:395-401

Shearer CA (1992) The role of woody debris. In: Bärlocher F (ed) The ecology of aquatic hyphomycetes. SpringerVerlag, Berlin, p 77-98

Shearer CA, Zare-Maivan H (1988) In vitro hyphal interactions among wood- and leaf-inhabiting ascomycetes and fungi imperfecti from freshwater habitats. Mycologia 80: 31-37

Simon M, Azam F (1989) Protein content and protein synthesis rate of planktonic marine bacteria. Mar Ecol Prog Ser 51:201-213

Sridhar KR, Bärlocher F (2000) Initial colonization, nutrient 
supply, and fungal activity on leaves decaying in streams. Appl Environ Microbiol 66:1114-1119

Suberkropp K (1991) Relationships between growth and sporulation of aquatic hyphomycetes on decomposing leaf litter. Mycol Res 95:843-850

Suberkropp K, Chauvet E (1995) Regulation of leaf breakdown by fungi in streams: influences of water chemistry. Ecology 76:1433-1445

Suberkropp K, Klug MJ (1976) Fungi and bacteria associated with leaves during processing in a woodland stream. Ecology 57:707-719

Suberkropp K, Klug MJ (1980) The maceration of deciduous leaf litter by aquatic hyphomycetes. Can J Bot 58: 1025-1031

Suberkropp K, Weyers H (1996) Application of fungal and bacterial production methodologies to decomposing

Editorial responsibility: Gary King,

Walpole, Maine, USA leaves in streams. Appl Environ Microbiol 62:1610-1615 Velji MI, Albright LJ (1993) Improved sample preparation for enumeration of aggregated aquatic substrate bacteria. In: Kemp PF, Sherr BF, Sherr EB, Cole JJ (eds) Handbook of methods in aquatic microbial ecology. Lewis Publishers, Boca Raton, p 139-142

Vining LC (1990) Functions of secondary metabolites. Annu Rev Microbiol 44:395-427

Weyers HS, Suberkropp K (1996) Fungal and bacterial production during the breakdown of yellow poplar leaves in 2 streams. J North Am Benthol Soc 15:408-420

Wohl DL, McArthur JV (2001) Aquatic actinomycete-fungal interactions and their effects on organic matter decomposition: a microcosm study. Microb Ecol 42:446-457

Zar JH (1984) Biostatistical analysis, 2nd edn. Prentice-Hall, Englewood Cliffs, NJ

Submitted: July 1, 2002; Accepted: September 1, 2002

Proofs received from author(s): December 9, 2002 